\title{
Trace Metal Contamination in Mangrove Sediments, Guanabara Bay, Rio de Janeiro, Brazil
}

\author{
Cassia O. Farias, Claudia Hamacher, Angela de Luca R. Wagener, ${ }^{*}$ Reinaldo C. de Campos \\ and José M.Godoy
}

\author{
Departamento de Química, Pontifícia Universidade Católica do Rio de Janeiro, R. Marquês de S. Vicente 225, \\ Gávea, 22453-900 Rio de Janeiro-RJ, Brazil
}

\begin{abstract}
A Baía de Guanabara no Rio de Janeiro tem sofrido profundas alterações ambientais. O aumento da concentração de metais-traço em seus sedimentos está entre as alterações mais relevantes. O objetivo deste trabalho foi verificar a contaminação por metais-traço e avaliar a disponibilidade em sedimentos de áreas de manguezais (Surui, Nova Orleans e Piedade). Concentrações de $\mathrm{Cd}, \mathrm{Zn}, \mathrm{Pb}, \mathrm{Ni}, \mathrm{Cu}$ e $\mathrm{Al}$ foram determinadas em segmentos de testemunhos após tratamento com $1 \mathrm{~mol} \mathrm{~L}^{-1}$ de $\mathrm{HCl}$ e com $\mathrm{HNO}_{3}$. Fe e $\mathrm{Mn}$ foram determinados na lixívia de $\mathrm{HNO}_{3}$ concentrado. As concentrações foram baixas em comparação com aquelas reportadas para a Baía de Guanabara e o Cd mostrou a mais alta recuperação em $1 \mathrm{~mol} \mathrm{~L}^{-1} \mathrm{HCl}(90 \%)$. Apesar de oxidados ou subóxicos os sedimentos mostraram SAV na faixa de 0,07 to $18,79 \mu \mathrm{mol}$ $\mathrm{g}^{-1}$ sugerindo heterogeneidade e desequilíbrio aparente. Óxidos de Fe, Mn, carbonatos e matéria orgânica são as fases que mais provavelmente controlam a biodisponibilidade dos metais.
\end{abstract}

The Guanabara Bay in Rio de Janeiro has undergone profound alterations of its natural environmental conditions. Metal concentration increase in sediments has been reported to be among these alterations. Trace-metal contamination and availability were studied in sediments of 3 mangrove areas of the bay. $\mathrm{Cd}, \mathrm{Zn}, \mathrm{Pb}, \mathrm{Ni}, \mathrm{Cu}$ and $\mathrm{Al}$ concentrations were determined in segments of sediment cores, after treatment with $1 \mathrm{~mol} \mathrm{~L}^{-1} \mathrm{HCl}$ and with concentrated $\mathrm{HNO}_{3}$. $\mathrm{Fe}$ and $\mathrm{Mn}$ were determined in the leach with $\mathrm{HNO}_{3}$. Concentrations were low in comparison to those reported for Guanabara Bay and Cd showed up to $90 \%$ recovery in the $\mathrm{HCl}$ extract. Sediments found to be oxic to suboxic showed AVS concentrations in range of 0.07 (bottom) to $18.79 \mu \mathrm{mol} \mathrm{g}{ }^{-1}$ (sub-surface) indicating heterogeneity and apparent disequilibrium. Fe and $\mathrm{Mn}$ oxides, carbonates and organic matter may be the most important phases controlling metal availability and distribution.

Keywords: trace metals, metal availability, mangrove, sediments

\section{Introduction}

Estuaries all over the world are prone to changes as a result of pollution and of several anthropogenic activities. The Guanabara Bay (Rio de Janeiro), which is an estuary for several rivers, presents high demographic density (7.8 million inhabitants) in its hydrographic basin of about $4080 \mathrm{~km}^{2}{ }^{1,2}$ The Guanabara Bay comprises the second largest Brazilian industrial region, the second largest port, two refineries, oil storage and distribution companies, naval services, dockyards and intense maritime and terrestrial transportation activities.

The bay, in function of the pronounced environmental degradation, had its original mangrove-covered area reduced from $258 \mathrm{~km}^{2}$ to $80 \mathrm{~km}^{2}$, currently concentrated in the

*e-mail: angela@rdc.puc-rio.br northwestern region. ${ }^{3}$ This ecosystem plays important role in the reproduction and preservation of ecologically and economically important species. ${ }^{4}$ However, oil pouring and the continuous release of contaminated effluents and untreated domestic sewage have threatened the integrity of these environments.

The contamination of marine environments by trace metals raises special interest, since metals cannot be eliminated and tend to accumulate in sediments, thus imposing acute or chronic toxicity to benthic organisms and representing serious risk to the health of consumers. ${ }^{5,6}$

There are reports of high concentrations of metals in the surface sediments of the Guanabara Bay. ${ }^{7-9}$ However, most works report the total concentration of metals, what impairs estimating the toxicity potential and bioavailability. Machado and co-workers ${ }^{10,11}$ present concentration of some metals extracted with $\mathrm{HCl} 0.1 \mathrm{~mol} \mathrm{~L}^{-1}$ in mangrove areas 
of Guanabara Bay. In Gramacho, an urban garbage disposal site, the concentrations obtained for one core demonstrated strong increase from past to present periods.

The fraction of metals in sediments considered as bioavailable is that found in the dissolved phase. Thus, sediments rich in solids that retain metals under insoluble forms shall impose no toxicological responses to organisms. ${ }^{12}$ The distribution of metals between sediment and interstitial water is basically controlled by the presence of fine particles, by the quantity and quality of the organic matter and by production of sulfides. Microbial degradation allied to large organic matter content in sediments, generally removes all molecular oxygen beneath the surface layer and creates ideal conditions for the reduction of sulfate into sulfide. ${ }^{5}$ Thus, the redox (reduction-oxidation) potential is an important factor controlling the retention of trace metals in sediments and, along with the interstitial water $\mathrm{pH}$, may change the concentration of dissolved metals and increase its availability for marine organisms. ${ }^{13}$

Mangrove sediments are generally considered anaerobic and reduced as well as being rich in sulfide and organic matter. ${ }^{14,15}$ According to Silva and Tam and Wong, ${ }^{13,16,17}$ these conditions favor the retention of trace metals, which can be mobilized by re-oxidation of sulfides occurring between tides. However, most metal assessment in mangrove sediments does not show experimental evidences that sulfides are indeed the important phases controlling metal availability in these ecosystems.

The relation between the concentration of metals extracted from sediment with cold $1 \mathrm{~mol} \mathrm{~L}^{-1} \mathrm{HCl}$ (Simultaneously Extracted Metals-SEM) and that of sulfides obtained from the same extract (Acid Volatile Sulfides-AVS) has been widely used as a proxy for potential metal bioavailability, in the case of metals that form insoluble sulfides. ${ }^{12,18}$

The rationale behind this method is that some metals (Ni, $\mathrm{Zn}, \mathrm{Cd}$ and $\mathrm{Cu}$ among others) accumulate in the sulfide phase because the sulfide ion successfully competes with other binding agents, both in the particulate phase and in the dissolved phase, to form insoluble sulfides. ${ }^{19}$ Since the solubility products of these sulfides are very low, the metal activity in water is kept below the threshold for toxic reactions. According to Di Toro et al., ${ }^{12}$ the SEM/AVS molar ratio may aid in the bioavailability evaluation of these metals in the sediment. For values of this ratio below 1 , contaminants in sediments do not cause acute toxicity. Studies have demonstrated that the mortality rate of species increases if the molar ratio is found between 1.5 and 2.5. ${ }^{20}$

Rickard and Morse, ${ }^{21}$ however, point out that AVS is a complex and variable component which does not represent any simple group of sediment component. Therefore, the critical SEM/AVS may be different for sediments with different AVS relative sources. Mackey and Mackay ${ }^{22}$ when studying the spatial distribution of AVS and metal bioavailability in mangroves of Brisbane River in Australia observed large spatial heterogeneity, but found, in general, low AVS levels (0.33-22.61 $\mu$ mol S g $\left.{ }^{-1}\right)$, which were ascribed to the sampling occurring in winter, when sulfate reduction would be low, and to working with surface sediment samples.

The initial objectives of the present study were: to evaluate the presence of potentially toxic metals in sediments of some mangrove areas of the Guanabara Bay; to search for vertical gradients of contamination by toxic metals in these sediment; and to test the use of the SEM/ AVS ratio as a tool to estimate metal availability and toxicity potential in mangroves.

\section{Experimental}

\section{Study area}

The present work was conducted in mangrove areas of Suruí, Nova Orleans and Piedade located in the northnortheastern portion of the Guanabara Bay (Figure 1). Piedade is close to the Environmental Protection Area of Guapimirim, which is considered as relatively pristine in relation to the other regions of the bay. The Guanabara Bay is located in a micro-tide region (tide amplitude of $0.7 \mathrm{~m})$.

Suruí and Nova Orleans mangroves were affected in 2000 by the spill of about $1800 \mathrm{~m}^{3}$ of oil. The aerial inspection performed shortly after the oil spill showed that the Suruí mangrove, despite being approximately 14 $\mathrm{km}$ away from the spill site, was severely affected due to the action of tidal currents. The work of Nudi demonstrated the presence of oil in Suruí and Nova Orleans in the year of $2003 .^{23}$ Since the oil spill occurred at the industrial region (northwestern part of the bay), where the main sources of metals are found, the migration of oil towards Suruí and Nova Orleans shows the possibility that other contaminants, released in the same region, may be as well transported to these mangrove areas under certain tide conditions.

In order to assess metal contamination in the cited mangroves, $\mathrm{Cd}, \mathrm{Zn}, \mathrm{Pb}, \mathrm{Ni}, \mathrm{Cu}$ and $\mathrm{Al}$ concentrations were determined in sediment cores after treating the samples with concentrated $\mathrm{HNO}_{3}$ to obtain what was denominated " $\mathrm{HNO}_{3}$ leaching" metal $\left(\mathrm{MeHNO}_{3}\right)$, and with $1 \mathrm{~mol} \mathrm{~L}^{-1} \mathrm{HCl}$ to obtain the "simultaneously extracted metal" (MeHCl). Fe and $\mathrm{Mn}$ were only determined in the $\mathrm{HNO}_{3}$ leaching. 

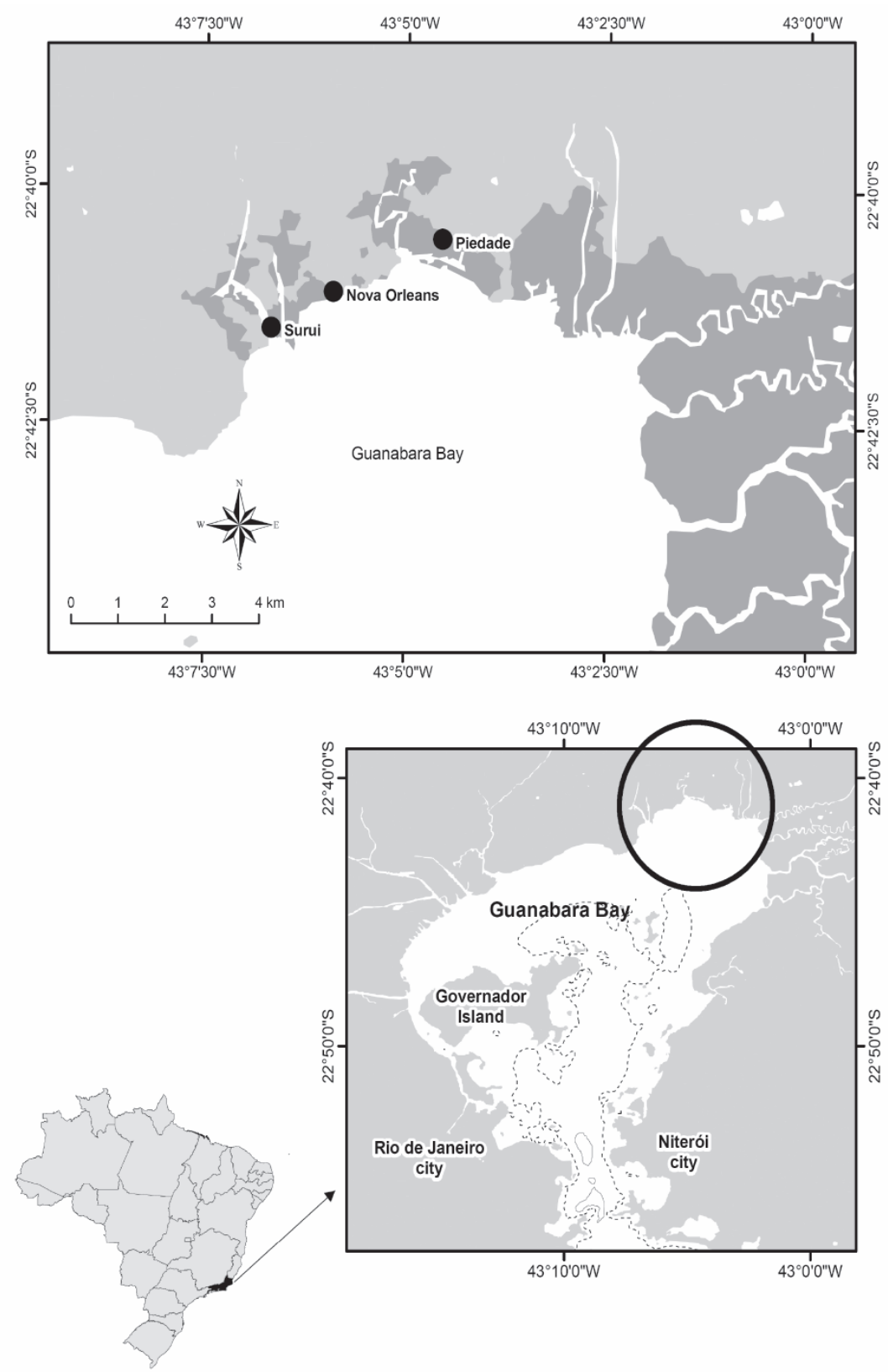

Figure 1. Map of Guanabara Bay showing the mangrove areas of Surui, Nova Orleans and Piedade.

\section{Sampling}

The sampling was performed in September 2003 (springtime) in the low tide period. Two stations were selected in the Suruí (S1, dominated by Rizophora mangle, and S2, dominated by Laguncularia racemosa) and Nova Orleans (NO1 and NO2, both dominated by Avicennia schauleriana): the first station was positioned at the fringe and the second was at the core of the mangrove area, approximately $100 \mathrm{~m}$ from the first station. Elevation of $\mathrm{S} 2$ and $\mathrm{NO} 2$ in respect to the stations at the fringe is of about $0.20 \mathrm{~m}$; therefore they are also subjected to inundation during high tide. ${ }^{24}$ In Piedade
(P, dominated by Laguncularia racemosa and Avicennia schauleriana), samples were collected only at the fringe. In each station, six cores were sampled along a $20 \mathrm{~m}$ long transect parallel to the bay margin. Two cores were sampled at the transect mid-point, and one core was collected at 10 and $20 \mathrm{~m}$, respectively, from each side of the mid point. Five out of the six cores were used to produce composite samples to better represent the concentration levels in each sampling station, since mangrove sediments tend to show significant space heterogeneity.

The $1 \mathrm{~m}$ cores were sampled with a piston-type sampler specially designed to avoid deformations in samples, and 
equipped with $7 \mathrm{~cm}$ diameter aluminum tubes. One of the cores collected in the mid point was used to measure $\mathrm{pH}$, Eh and to perform the grain size determination.

The cores were sectioned in a $0-3 \mathrm{~cm}$ superficial layer; in $5 \mathrm{~cm}$ layers up to the depth of $38 \mathrm{~cm}$; and into $10 \mathrm{~cm}$ layers from 38 to about $100 \mathrm{~cm}$ depth. Generally, the cores provided up to 13 layers ( $88 \mathrm{~cm}$ depth). Sediments layers from corresponding depths were mixed together to produce composite samples for each station. The core intended to the attainment of ancillary data was also sliced as described above.

Samples aimed at the determination of metals were removed from the inner part of the cores to avoid contamination through contact with the metallic tube, and thereafter stored in polyethylene flasks at $-20{ }^{\circ} \mathrm{C}$. Subsamples were stored in previously decontaminated flasks, adequate for ASV determinations, and frozen at $-20{ }^{\circ} \mathrm{C}$ until analysis. To avoid ASV oxidation the sub-sampling glass vials (pre treated with $\mathrm{N}_{2}$ flow) were pressed into the sediment until completely full and then immediately capped and sealed.

All samples were examined in relation to the presence of macro debris which were removed whenever present.

\section{Analytical determinations}

$\mathrm{pH}$ and Eh were measured by immersing a combined electrode (DIGIMED pH meter; glass electrode combined to a $\mathrm{Ag} / \mathrm{AgCl}$ reference electrode) and a platinum electrode (ORION 250A Eh meter), respectively, deeply into each sediment layer immediately after its extrusion from the aluminum tube. A sub-sample was removed for the grain size determination. All Eh data are reported as electrode potentials in the standard hydrogen electrode scale.

The EPA method (PB93-155901) was used for the AVS (Acid Volatile Sulfide) determination. Glass vials fitting approximately $7 \mathrm{~g}$ of wet sediment were filled to the top with sediments before storage at $-20^{\circ} \mathrm{C}$. These vials were open and the content was immediately transferred to the adequate glass equipment, which was assembled as described in the method. Sulfides were converted into $\mathrm{H}_{2} \mathrm{~S}$ through acidification with $30 \mathrm{~mL}$ of $1 \mathrm{~mol} \mathrm{~L}^{-1} \mathrm{HCl}$ at room temperature. The produced $\mathrm{H}_{2} \mathrm{~S}$ was purged with nitrogen and retained in flask containing $\mathrm{NaOH}$ aqueous solution. Quantification of the acid-released $\mathrm{H}_{2} \mathrm{~S}$ was performed by colorimetric measurements, based on calibration curves obtained for sodium sulfide solutions of known concentration. This method proposed by Allen presented a detection limit of $0.02 \mu \mathrm{mol} \mathrm{g}^{-1}$ (dry weight). ${ }^{25}$

The resulting acid extract of each sample was filtered in $0.45 \mu \mathrm{m}$ cellulose acetate (Millipore) filter previously decontaminated with $10 \% \mathrm{HNO}_{3}$. Metals in this $\mathrm{HCl}$ extract $(\mathrm{Ni}, \mathrm{Cu}, \mathrm{Cd}, \mathrm{Zn}$ and $\mathrm{Pb})$ were determined as described below.

$\mathrm{Zn}$ and $\mathrm{Al}$ were determined through flame atomic absorption spectroscopy using a Varian AAS5 and the other metals $(\mathrm{Ni}, \mathrm{Cu}, \mathrm{Cd}$ and $\mathrm{Pb}$ ) were analyzed by graphite furnace atomic absorption spectroscopy using a Perkin-Elmer 1100. The analytical conditions are given under Table 1 .

Table 1. Instrumental conditions used for determination of the different elements

\begin{tabular}{lcccc}
\hline Element & $\begin{array}{c}\text { Pyrolysis } / \\
\left({ }^{\circ} \mathrm{C}\right)\end{array}$ & $\begin{array}{c}\text { Atomization / } \\
\left({ }^{\circ} \mathrm{C}\right)\end{array}$ & $\begin{array}{c}\text { Wavelength / } \\
(\mathrm{nm})\end{array}$ & Slit \\
\hline $\mathrm{Pb}$ & 800 & 1800 & 283.3 & $0.7 \mathrm{~nm}$ \\
$\mathrm{Cd}$ & 900 & 1600 & 228.8 & $0.7 \mathrm{~nm}$ \\
$\mathrm{Ni}$ & 1100 & 2500 & 232.0 & $0.2 \mathrm{~nm}$ \\
$\mathrm{Cu}$ & 1000 & 2300 & 324.8 & $0.7 \mathrm{~nm}$ \\
$\mathrm{Fe}$ & - & - & 248.3 & $100 \mu \mathrm{m}$ \\
$\mathrm{Mn}$ & - & - & 279.5 & $50 \mu \mathrm{m}$ \\
$\mathrm{Al}$ & - & - & 309.3 & $100 \mu \mathrm{m}$ \\
$\mathrm{Zn}$ & - & - & 213.9 & $100 \mu \mathrm{m}$ \\
\hline
\end{tabular}

For the determination of the "HNO $\mathrm{H}_{3}$ leaching metal", sediment samples were dried in stove at low temperature $\left(60^{\circ} \mathrm{C}\right)$ and grinded. Approximately $10 \mathrm{~mL}$ of Merck Suprapur nitric acid were added to $1 \mathrm{~g}$ of sediment for the digestion of the sample over $24 \mathrm{~h}$ at room temperature. After this period, the samples were heated at $80^{\circ} \mathrm{C}$ for 2 $\mathrm{h}$. The extract thus obtained was diluted to $30 \mathrm{~mL}$ with MILLI-Q water. $\mathrm{Fe}, \mathrm{Mn}, \mathrm{Zn}$ and $\mathrm{Al}$ were determined through flame atomic absorption spectroscopy, while $\mathrm{Cd}$, $\mathrm{Pb}, \mathrm{Ni}$ and $\mathrm{Cu}$ were determined by graphite furnace atomic absorption spectroscopy as described above.

The detection limits calculated as 3 times the standard deviation of the reagent blanks and given in $\mathrm{mg} \mathrm{kg}^{-1}$ for $\mathrm{HCl}$ and $\mathrm{HNO}_{3}$ extracts, respectively, were: $\mathrm{Cd}: 0.005$ and 0.017; Ni: 0.054 and 0.018 ; $\mathrm{Pb}: 0.036$ and 0.210 ; $\mathrm{Cu}$ : 0.022 and 0.054; Zn: 0.3 and 1.2; Fe (\%): 0.1; Mn: 0.3; Al: 0.045 and 0.031 . Quality assurance procedure included blank control and analysis of certified reference material MESS-3-NIST (see Table 2).

Grain size was determined through the wet sieving method using a $63 \mu \mathrm{m}$ diameter sieve. ${ }^{26}$

Total organic carbon $\left(\mathrm{C}_{\text {org }}\right)$ determination was performed in $10 \mathrm{mg}$ aliquots of sediment after eliminating carbonates with $2 \mathrm{~mol} \mathrm{~L}^{-1} \mathrm{HCl}$ (Suprapur Merck) and drying at $60^{\circ} \mathrm{C}$ to constant weight. Measurements were carried out in a TOC-5000A Shimadzu equipped with a SSM-5000A module for solid samples. Quantification was based on calibration curves $(r>0.99)$ prepared by using phthalate standard solutions of different concentrations.

Dating of the sediment cores was attempted by low energy gamma spectrometry using an intrinsic germanium detector 
Table 2. Results of the analysis of the MESS-3-NIST certified sediment

\begin{tabular}{lcc}
\hline Element & $\begin{array}{c}\text { Concentration } \\
\text { Found }\end{array}$ & $\begin{array}{c}\text { Certified Value } \\
\text { (MESS3-NIST) }\end{array}$ \\
\hline $\mathrm{Fe} /(\%)$ & 4.3 & $4.34 \pm 0.11$ \\
$\mathrm{Al} /(\%)$ & 8.1 & $8.59 \pm 0.23$ \\
$\mathrm{Cu} /\left(\mathrm{mg} \mathrm{kg}^{-1}\right)$ & 39 & $33.9 \pm 1.6$ \\
$\mathrm{Mn} /\left(\mathrm{mg} \mathrm{kg}^{-1}\right)$ & 313 & $324 \pm 12$ \\
$\mathrm{Ni} /\left(\mathrm{mg} \mathrm{kg}^{-1}\right)$ & 41 & $46.9 \pm 2.2$ \\
$\mathrm{Zn} /\left(\mathrm{mg} \mathrm{kg}^{-1}\right)$ & 140 & $159 \pm 8$ \\
$\mathrm{~Pb} /\left(\mathrm{mg} \mathrm{kg}^{-1}\right)$ & 21.9 & $21.1 \pm 0.7$ \\
$\mathrm{Cd} /\left(\mathrm{mg} \mathrm{kg}^{-1}\right)$ & 232 & $240 \pm 10$ \\
\hline
\end{tabular}

CANBERRA LEG 2000 and the procedure given in Godoy. ${ }^{27}$ ${ }^{210} \mathrm{~Pb}$ determination was based on the beta counting of the ${ }^{210} \mathrm{Bi}$ after chemical separation of the lead with $\mathrm{PbCrO}_{4}$. The detection limit for ${ }^{210} \mathrm{~Pb}$ was of $1.4 \mathrm{pCi}$ per $\mathrm{g}$.

\section{Statistical evaluation}

The Pearson test was employed to verify possible correlations among variables and the Kruskal-Wallis test was used to search for significance of observed differences among samples. Principal Component Analysis was applied to the entire data set after normalization. The software STATISTICA 6.0 was used in all cases.

\section{Results and Discussion}

\section{Dating}

The ${ }^{210} \mathrm{~Pb}$ profiles showed scattered data and absence of trends up to about $1 \mathrm{~m}$ depth, therefore no useful chronological information resulted from the dating procedure. According to Walsh and Nittrouer ${ }^{28}$ mangrove sediment profiles exhibiting uniform or fluctuating activities may have formed during large sediment transport events and reflect rapid accumulation. These authors also found uniform profiles up to depths of $1 \mathrm{~m}$ or more in mangrove cores indicating non-steady state ${ }^{210} \mathrm{~Pb}$ activities. The increase by a factor of 10 in sedimentation rates in the inner areas of Guanabara Bay is well known and Amador reports actual sedimentation rates for these areas greater than $4.5 \mathrm{~cm}$ year ${ }^{-1} .{ }^{29}$ During the second half of the twenty century deforestation in the hydrographic basin and canalization of many rivers crisscrossing the mangrove areas resulted in increasing sediment transport to these areas. Such increase may account for the rapid accumulation of sediments indicated by the ${ }^{210} \mathrm{~Pb}$ fluctuations along the sediment profiles. Bioturbation alone cannot explain the ${ }^{210} \mathrm{~Pb}$ fluctuations observed up to depths of about $1 \mathrm{~m}$.

\section{Statistical evaluation}

Tables 3 and 4 show the Pearson correlation matrixes. The rather small coefficients in Table 3 represent weak correlations among metals extracted with $\mathrm{HCl}$ as well as between those and ancillary data. Robust correlations were found for some metals ( $\mathrm{Al}, \mathrm{Fe}$ and $\mathrm{Ni}$ ) in the $\mathrm{HNO}_{3}$ extract (Table 4), however the highest coefficients were obtained for the correlations of $\mathrm{C}_{-\mathrm{org}}$, $\%$ of grains $<63 \mu \mathrm{m}, \mathrm{Al}$ and $\mathrm{pH}$.

In Figure 2 appears the plot of factors 1 and 2 of the PCA, which are responsible for $34 \%$ and $16 \%$ of the variance, respectively. A total of 5 factors with eigenvalues higher than 1 were obtained, however, factors 3,4 and 5 together contribute with less than $24 \%$ for the overall variance. Components of factor 1 with loadings $>0.7$ are $\mathrm{pH}, \mathrm{Zn}, \mathrm{Al}$ (negatively correlated), $\mathrm{C}_{\text {org }}$ and fraction $<63$ $\mu \mathrm{m}$, while $\mathrm{Cu}, \mathrm{Pb}, \mathrm{Cd}$ and $\mathrm{Fe}$ show weaker correlations in this factor $(0.6<$ loadings $<0.7)$. Components in factor 2 with loadings $\geq 0.7$ are $\mathrm{Eh}$ and $\mathrm{CuHCl}$ and $\mathrm{PbHCl}$.

The PCA shows (Figure 2) that surface samples (in the lower quarters) are distinct from deeper sediments (in the upper quarters) and this is principally due to the higher Eh and $\mathrm{CuHCl}$ content in the former. Surui appearing in Figure 2 in the right quarters is distinct from $\mathrm{NO}$ and $\mathrm{P}$

Table 3. Significant Pearson linear correlation coefficients at $\mathrm{p}<0.05$; metals extracted in the $\mathrm{HCl}$ medium. Robust correlations are highlighted in bold

\begin{tabular}{|c|c|c|c|c|c|c|c|c|c|c|c|}
\hline & $\mathrm{pH}$ & Eh & AVS & $\mathrm{Zn}_{\mathrm{HCl}}$ & $\mathrm{Ni}_{\mathrm{HCl}}$ & $\mathrm{Cu}_{\mathrm{HCl}}$ & $\mathrm{Cd}_{\mathrm{HCl}}$ & $\mathrm{Pb}_{\mathrm{HCl}}$ & $\mathrm{Al}_{\mathrm{HCl}}$ & $\mathrm{C}_{\text {org }}$ & $<63 \mu \mathrm{m}$ \\
\hline $\mathrm{pH}$ & & & & -0.38 & & & & & -0.38 & 0.53 & 0.77 \\
\hline Eh & & & 0.25 & 0.43 & & 0.56 & & 0.28 & & & \\
\hline AVS & & 0.25 & & & & 0.30 & & 0.52 & & & \\
\hline $\mathrm{Zn}_{\mathrm{HCl}}$ & -0.38 & 0.43 & & & & 0.28 & & & 0.30 & & \\
\hline $\mathrm{Ni}_{\mathrm{HCl}}$ & & & & & & & & 0.27 & & & \\
\hline $\mathrm{Cu}_{\mathrm{HCl}}$ & & 0.56 & 0.30 & 0.28 & & & & 0.52 & & & \\
\hline $\mathrm{Cd}_{\mathrm{HCl}}$ & & & & & & & & 0.40 & & & \\
\hline $\mathrm{Pb}_{\mathrm{HCl}}$ & & 0.28 & 0.52 & & 0.27 & 0.52 & 0.40 & & & & \\
\hline $\mathrm{Al}_{\mathrm{HCl}}$ & -0.38 & & & 0.30 & & & & & & -0.42 & -0.40 \\
\hline $\mathrm{C}_{\mathrm{org}}^{\mathrm{HCl}}$ & 0.53 & & & & & & & & -0.42 & & 0.78 \\
\hline$<63 \mu \mathrm{m}$ & 0.77 & & & & & & & & -0.40 & 0.78 & \\
\hline
\end{tabular}


Table 4. Significant Pearson linear correlation coefficients at $\mathrm{p}<0.05$; metals extracted in the $\mathrm{HNO}_{3}$ medium. Robust correlations are highlighted in bold

\begin{tabular}{|c|c|c|c|c|c|c|c|c|c|c|c|c|}
\hline & $\mathrm{pH}$ & Eh & $\mathrm{Zn}$ & $\mathrm{Ni}$ & $\mathrm{Cu}$ & $\mathrm{Cd}$ & $\mathrm{Pb}$ & $\mathrm{Al}$ & $\mathrm{Fe}$ & $\mathrm{Mn}$ & $\mathrm{C}_{\mathrm{org}}$ & $<63 \mu \mathrm{m}$ \\
\hline $\mathrm{pH}$ & & & & -0.42 & & & & -0.67 & & & 0.53 & 0.77 \\
\hline Eh & & & & & 0.34 & & & & -0.31 & & & \\
\hline $\mathrm{Zn}$ & & & & 0.54 & 0.47 & 0.29 & 0.48 & 0.38 & 0.44 & & & \\
\hline $\mathrm{Ni}$ & -0.42 & & 0.54 & & 0.33 & & & 0.62 & 0.66 & 0.48 & -0.28 & -0.32 \\
\hline $\mathrm{Cu}$ & & 0.34 & 0.47 & 0.33 & & & & & & 0.35 & & \\
\hline $\mathrm{Cd}$ & & & 0.29 & & & & 0.38 & & & & & \\
\hline $\mathrm{Pb}$ & & & 0.48 & & & 0.38 & & 0.37 & 0.26 & -0.40 & -0.29 & \\
\hline $\mathrm{Al}$ & -0.67 & & 0.38 & 0.62 & & & 0.37 & & 0.61 & & -0.69 & -0.78 \\
\hline $\mathrm{Fe}$ & & -0.31 & 0.44 & 0.66 & & & 0.26 & 0.61 & & 0.27 & -0.46 & -0.32 \\
\hline $\mathrm{Mn}$ & & & & 0.48 & 0.35 & & -0.40 & & 0.27 & & & 0.26 \\
\hline & 0.53 & & & -0.28 & & & -0.29 & -0.69 & -0.46 & & & 0.78 \\
\hline$<63 \mu \mathrm{m}$ & 0.77 & & & -0.32 & & & & -0.78 & -0.32 & 0.26 & 0.78 & \\
\hline
\end{tabular}

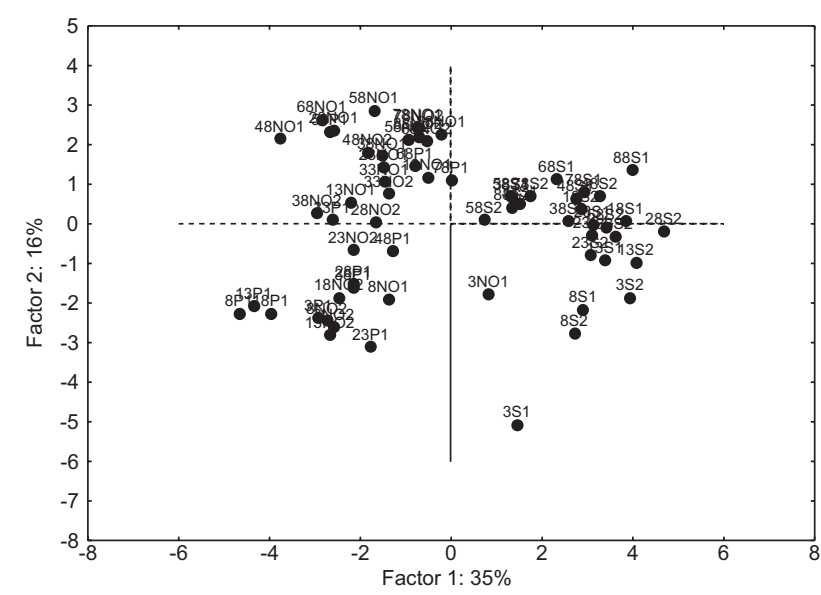

Figure 2. Principal Component Analysis of the entire data set. S1, S2, NO1, NO2, and P stand for Surui, station 1 and 2; Nova Orleans, station 1 and 2; and Piedade. The numbers ahead of $\mathrm{NO}, \mathrm{S}$ and $\mathrm{P}$ refer to the depth (in $\mathrm{cm}$ ) in the sediment column.

(left quarters) mainly because of the lower $\mathrm{C}_{\text {org }}$ and content of fine grains.

\section{pH and Eh}

In Surui and Nova Orleans Eh showed sharp decrease with depth in the first $20-25 \mathrm{~cm}$ of the sediment column. Below these depths there were no significant variations or trends. Contrary to the expectation, sediments, in general, presented Eh characteristic of oxidized to suboxic environments. Only in the two lower sediment layers of $\mathrm{S} 2 \mathrm{Eh}$ was below $-100 \mathrm{mV}(-136 \mathrm{mV}$ and $-108 \mathrm{mV}$, respectively). Eh values in surface sediments of stations 2 , at the core of the mangrove areas, were more negative than in stations 1 at the fringe. The oxic-suboxic boundary was also at shallower depths: at about $13 \mathrm{~cm}$ in $\mathrm{S} 1,3 \mathrm{~cm}$ in $\mathrm{S} 2,13 \mathrm{~cm}$ in $\mathrm{NO} 1$, and $8 \mathrm{~cm}$ in $\mathrm{S} 2$.

In mangroves, excavation by crabs and other animals may disturb considerably the original structure of the first

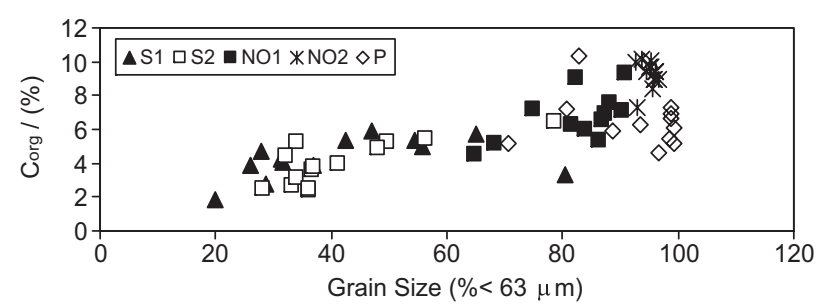

Figure 3. Plot of $\mathrm{C}_{\text {org }}$ as function of grain size $<63 \mu \mathrm{m} ; \mathrm{S}, \mathrm{NO}$ and P stand for Surui, Nova Orleans and Piedade, while 1 and 2 represent station 1 and 2 in each mangrove.

20-30 cm of sediment column. Bioturbation, seawater infiltration due to tidal action, the shifting of the water table, and the release of molecular oxygen by roots are processes that may explain the suboxic or even oxic condition of the studied sediments. ${ }^{13}$ Sediments from Surui and Nova Orleans showed well defined Eh depth profiles, as depicted in Figure 4, and only in Piedade the lack of significant Eh variations in the upper $20 \mathrm{~cm}$ suggest bioturbation. There, an Eh maximum at about $40 \mathrm{~cm}$ as well as the positive values up to about $60 \mathrm{~cm}$ may result from oxygen release from roots.

Clark observed in Avicennia-dominated mangrove that seasonal changes in the position of the water table were responsible for shifts in the oxic-anoxic horizon. ${ }^{13}$ These authors report that although sediments were rich in clay and of low porosity, there were hydrological evidences of water table shifting position in the sediments. In the present case, the lowest Eh was found in the deeper layers of the sand-rich sediments of Surui, while in the other stations, as in Piedade, where redox potential was positive up to the depth of $58 \mathrm{~cm}$, sediments were clay-rich with an average grain size $<63 \mu \mathrm{m}$ around $90 \%$. In September 2003 rainfall was of $25 \mathrm{~mm}$, a low index for the area, and temperatures were around $24^{\circ} \mathrm{C}$. Therefore, it is unlikely that water table intrusion had significant influence in the observed redox condition. Prevailing temperatures also cannot be considered a limiting factor for bacterial activity 

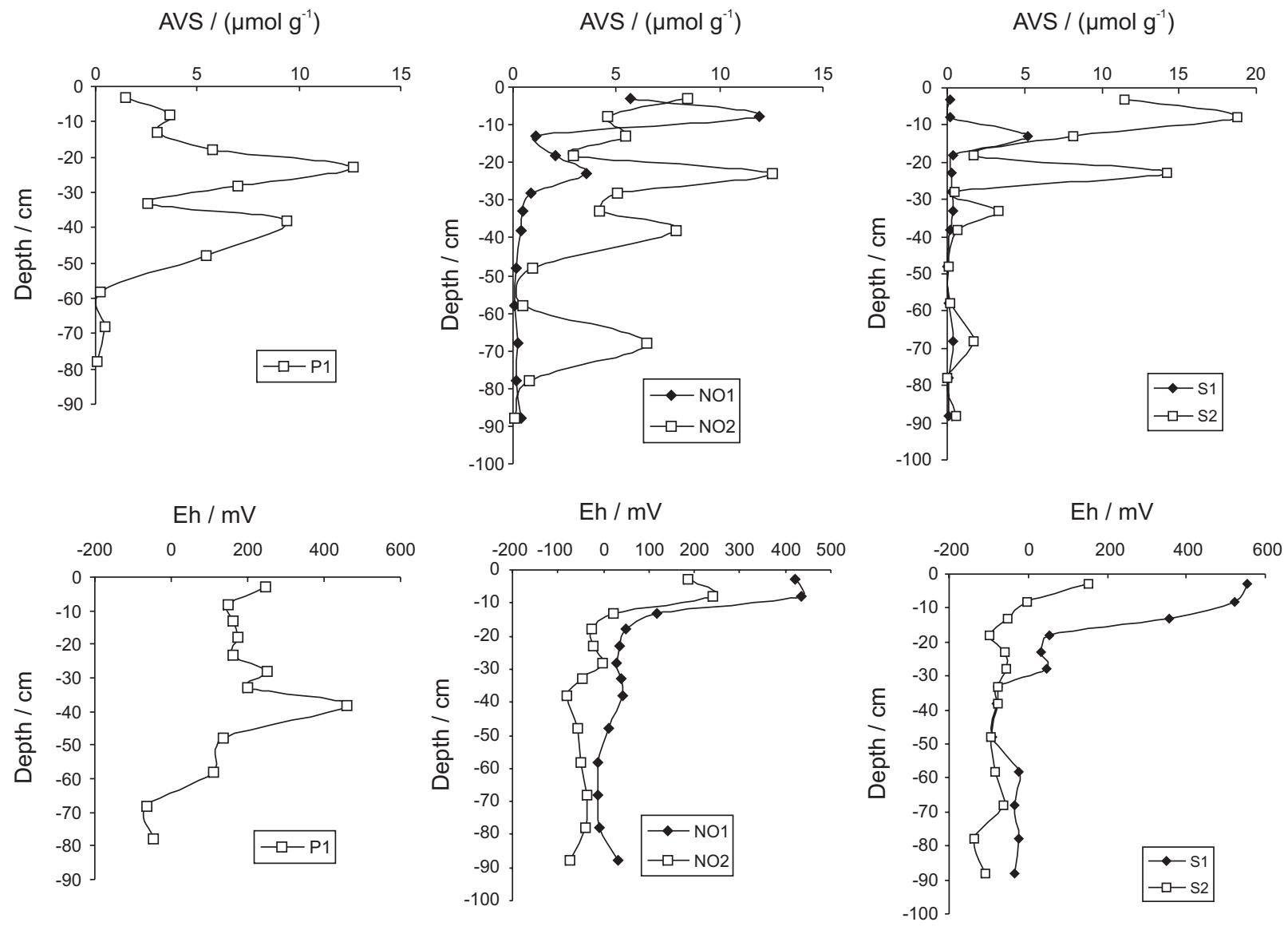

Figure 4. ASV ( $\mu \mathrm{mol} \mathrm{g}^{-1}$ ) and $\mathrm{Eh}(\mathrm{mV})$ depth profile in the mangroves of Piedade, Nova Orleans (stations 1 and 2) and Surui (stations 1 and 2).

as suggested in the study of Mackey and Mackay.2 It is, however, possible that in the summer with air temperatures above $35^{\circ} \mathrm{C}$ reducing conditions may be more pronounced in the upper sediments layers.

None of the samples had a bulk Eh sufficiently negative for reduction of sulfate. The $\mathrm{pE}$ required for a significant reduction of sulfate to sulfide, calculated for neutral $\mathrm{pH}$ and using equilibrium considerations, is $<-3$ (Eh at $25^{\circ} \mathrm{C}<-177 \mathrm{mV}$ ). ${ }^{30}$

In Piedade $\mathrm{pH}$ was constant to about $20 \mathrm{~cm}$ depth, possibly due to bioturbation, displaying thereafter fluctuations and a slight decreasing trend with depth. The average $\mathrm{pH}$ value was of $7.78 \pm 0.23$. In Nova Orleans, pH was between 7.70 (top layer) and 6.68 (bottom layer) in NO1, and 7.26 (top layer) and 7.12 (bottom layer) in NO2. Amongst the studied areas Suruí has the most acidic sediments (5.85 and 5.42 in the two top layers of $\mathrm{S} 1$ growing towards the bottom to 6.70 ; 6.39 to 6.73 in S2); the acid values in the two upper sediment layer are indicative of on going oxidative processes. The predominance of Avicennia in Piedade and Nova Orleans may be responsible for the higher $\mathrm{pH}$ in sediments of these sites. ${ }^{31}$

\section{Organic carbon and grain size}

Table 5 shows the averages and the data variability along the cores (expressed as standard deviation) for $\mathrm{C}_{\text {org }}$ and grain size $(<63 \mu \mathrm{m})$ in each station. Figure 3 shows the good relation between these variables $(r=0.78$; $p<0.05$; $\mathrm{n}=64$ ), and the concentration range for each core. In the Suruí area, where sand prevails, $\mathrm{C}_{\text {org }}$ concentrations are lower in relation to the other muddier areas. $\mathrm{C}_{\text {org }}$ depth profiles distribution show no smooth trends but fluctuations along the cores. In S2 the concentrations increase from surface to bottom. The concentrations are, in general, elevated along the entire profiles, and concentration differences were more pronounced between stations than between layers of a single core as show the small standard deviations of the average for $\mathrm{C}_{\text {org }}$ given in Table 5.

\section{Acid volatile sulfides}

Equilibrium calculations, as discussed under item " $p H$ and Eh", and the measured redox potentials demonstrate predominance of suboxic conditions below surface and a 
prevailing environment which do not concur with reduction of sulfate. In spite of this, AVS concentrations (Figure 4) ranged from 0.19 to $11.56 \mu \mathrm{mol} \mathrm{g}^{-1}$ in surface samples and from 0.07 to $0.59 \mu \mathrm{mol} \mathrm{g}^{-1}$ in bottom samples. The values at the surface are comparable to the reported by Mackey and Mackay for mangroves in the Brisbane River, Australia $(\mathrm{Eh}>100 \mathrm{mV}) .{ }^{22}$ Depth profiles in station 1 (the closest to the bay) of Nova Orleans and Suruí show a decreasing concentration trend towards the bottom, which is superimposed by oscillations. This was more evident in stations 2, where lower Eh values were found in both mangroves. Such oscillations, also present in Piedade, are neither associated to Eh nor to $\mathrm{pH}$.

The AVS concentrations in station 1 of the Suruí are at least one order of magnitude lower than in Nova Orleans and Piedade. In station 2, surface concentrations are more elevated and similar to those in Nova Orleans, with a subsurface maximum of about $18 \mu \mathrm{mol} \mathrm{g}{ }^{-1}$. There is a very weak correlation between the entire set of AVS and Eh data as shown in Table 4.

The AVS concentrations are unexpectedly low considering the high $\mathrm{C}_{\text {org }}$ content. $\mathrm{pE}$ in the sediments is far more positive than that in which the reduction of sulfate into sulfide. If conditions are anoxic in other periods therefore leading to extensive formation of sulfides, these species are either almost completely oxidized up to depths of $1 \mathrm{~m}$ in the sediment -although it seems improbable that microbial activity is equally active from surface up to these depth- or the formed sulfides cannot be assessed by the AVS extraction procedure, as Cooper and Morse ${ }^{18}$ and Rickard and Morse suggest. ${ }^{21}$ These authors show that the type of mineral prevailing in the sediment as well as particle size may influence solubility in this extraction medium, which may lead to underestimating the potential bioavailability of several metals. It should be considered as well that sediments are heterogeneous environments, rich in micro porous structures where the localized formation of sulfides can occurs catalyzed by microorganisms in anaerobic microenvironments. This would explain the appearance of sulfide concentrations of the same order of magnitude in both aerobic and suboxic bulk conditions. The kinetics of the redox (reduction-oxidation) processes that many times is slow and generates conditions of thermodynamic disequilibrium, may favor the stability of these phases in microenvironments, where the molecular oxygen diffusional fluxes are small. ${ }^{30}$

The quality of the organic matter available for degradation in the sediments may also result in low respiration rates, similarly to the observed in Guanabara Bay, where sulfate oxidation ceases below $10 \mathrm{~cm}$ depth in the sediments, although sulfate is present and $\mathrm{C}_{\text {org }}$ is higher than $2 \%{ }^{32}$ The elevated local temperatures all over the year promote fast degradation of organic matter in the water column as well as in the upper layers of the sediments, and the resulting product of this intense microbial activity is a refractory organic matter of little nutritional value. ${ }^{32}$ Such substances, when prevailing in the mangrove sediment, cause a decreasing sulfate reducing activity downwards the sediment column, and generate the observed AVS profiles. The relative constancy of $\mathrm{C}_{\text {org }}$ along most cores could be ascribed to bioturbation but this cannot be assumed for depths below $40 \mathrm{~cm}$, the maximum depth of a crab burrow. Possibly a substantive fraction of the residual organic matter is principally of refractory nature.

Table 5. Metal concentrations $\left(\mathrm{mg} \mathrm{kg}^{-1}\right)$, organic carbon content $\left(\mathrm{C}_{\mathrm{org}}\right)$ and grain size $<63 \mu \mathrm{m}$ in the $88 \mathrm{~cm}$ of core. Standard deviations $(\mathrm{SD})$

\begin{tabular}{|c|c|c|c|c|c|c|c|c|c|c|}
\hline \multirow[t]{2}{*}{ Stations } & \multicolumn{2}{|c|}{$\mathrm{P}$} & \multicolumn{2}{|c|}{ NO1 } & \multicolumn{2}{|c|}{$\mathrm{NO} 2$} & \multicolumn{2}{|c|}{$\mathrm{S} 1$} & \multicolumn{2}{|c|}{$\mathrm{S} 2$} \\
\hline & Average & $\mathrm{SD}$ & Average & $\mathrm{SD}$ & Average & $\mathrm{SD}$ & Average & $\mathrm{SD}$ & Average & $\mathrm{SD}$ \\
\hline $\mathrm{Zn}\left(\mathrm{HNO}_{3}\right)$ & 37.0 & 7.6 & 43.2 & 9.3 & 31.0 & 5.1 & 35.2 & 8.3 & 39.5 & 14.7 \\
\hline $\mathrm{Zn}(\mathrm{HCl})$ & 7.0 & 2.7 & 9.0 & 2.5 & 7.9 & 2.2 & 9.7 & 8.6 & 8.9 & 3.5 \\
\hline $\mathrm{Ni}\left(\mathrm{HNO}_{3}\right)$ & 4.0 & 0.2 & 6.1 & 1.6 & 4.7 & 0.5 & 5.6 & 0.8 & 5.8 & 1.5 \\
\hline $\mathrm{Ni}(\mathrm{HCl})$ & 1.6 & 1.0 & 0.7 & 0.5 & 0.2 & 0.1 & 0.6 & 0.1 & 1.4 & 0.7 \\
\hline $\mathrm{Cu}\left(\mathrm{HNO}_{3}\right)$ & 3.8 & 0.7 & 4.7 & 1.4 & 3.4 & 0.9 & 3.5 & 0.8 & 3.4 & 1.1 \\
\hline $\mathrm{Cu}(\mathrm{HCl})$ & 0.1 & 0.09 & 0.2 & 0.3 & 0.4 & 0.3 & 0.4 & 0.7 & 0.2 & 0.2 \\
\hline $\mathrm{Cd}\left(\mathrm{HNO}_{3}\right)$ & 0.10 & 0.06 & 0.09 & 0.03 & 0.07 & 0.01 & 0.08 & 0.04 & 0.07 & 0.03 \\
\hline $\mathrm{Cd}(\mathrm{HCl})$ & 0.05 & 0.05 & 0.06 & 0.03 & 0.02 & 0.01 & 0.03 & 0.01 & 0.03 & 0.01 \\
\hline $\mathrm{Pb}\left(\mathrm{HNO}_{3}\right)$ & 13.6 & 2.4 & 9.1 & 1.6 & 9.8 & 1.8 & 12.8 & 4 & 12.8 & 2.5 \\
\hline $\mathrm{Pb}(\mathrm{HCl})$ & 4.3 & 2.6 & 2.5 & 0.8 & 3.7 & 2.3 & 2.8 & 1.7 & 3.9 & 2.5 \\
\hline $\mathrm{Al}\left(\mathrm{HNO}_{3}\right)$ & 5647 & 464 & 6421 & 1424 & 5538 & 372 & 9021 & 1124 & 10131 & 2546 \\
\hline $\mathrm{Al}(\mathrm{HCl})$ & 862 & 253 & 933 & 210 & 716 & 130 & 951 & 247 & 1241 & 474 \\
\hline $\mathrm{Fe} /(\%)$ & 1.9 & 0.3 & 1.9 & 0.5 & 1.6 & 0.3 & 2.0 & 0.3 & 2.1 & 0.2 \\
\hline $\mathrm{Mn}\left(\mathrm{HNO}_{3}\right)$ & 169 & 60 & 360 & 99 & 183 & 69 & 169 & 28 & 147 & 51 \\
\hline $\mathrm{C}_{\text {org }} /(\%)$ & 6.41 & 1.49 & 6.73 & 1.38 & 9.26 & 0.77 & 4.32 & 0.96 & 3.84 & 1.14 \\
\hline$<63 \mu \mathrm{m} /(\%)$ & 92.20 & 9.47 & 81.83 & 1.48 & 95.04 & 1.24 & 42.16 & 17.63 & 38.64 & 7.99 \\
\hline
\end{tabular}


Machado found maximum AVS concentration of 245 $\mu \mathrm{mol} \mathrm{\textrm {g } ^ { - 1 }}$ at 2-4 $\mathrm{cm}$ depth in a core from Guanabara Bay and of $314 \mu \mathrm{mol} \mathrm{g}^{-1}$ at $28-30 \mathrm{~cm}$ in a core from the nearby Iguaçu River. ${ }^{9}$ Both cores were sampled in sites with strong eutrophic conditions in the water column and where sediments are highly anoxic.

\section{Metal concentrations in sediments}

Table 5 presents the averages of metal concentrations after extraction with $\mathrm{HCl} 1 \mathrm{~mol} \mathrm{~L}^{-1}$ and digestion with $\mathrm{HNO}_{3}$. Fe and $\mathrm{Mn}$ were not determined in the extraction with $\mathrm{HCl}$, since, according to Allen, this extraction procedure is not efficient for these two metals. ${ }^{25}$ Aluminum may be mobilized through $\mathrm{HCl}$, for example, from iron oxo-hydroxides or along with some carbonate. Carbonate and unconsolidated oxide phases with large active surfaces may contain substantial amounts of adsorbed metals, which can be recovered in the $\mathrm{HCl}$ medium.

Metal concentrations were not normalized to aluminum, iron, \% fine grains or $\mathrm{C}_{\text {org }}$ because correlations with these variables were weak or not existing. The discussion will be based on the absolute concentrations and on the $[\mathrm{MeHCl}] /\left[\mathrm{MeHNO}_{3}\right]$ ratio. Normalization to the \% fine grains will be used only to facilitate sorting the mangroves as for differences in contamination level.

As expected, aluminum shows good correlation with iron in the $\mathrm{HNO}_{3}$ extract, however both metals appear negatively correlated with the $\%$ of fine grains $(<63$ $\mu \mathrm{m})$. Tessier report that increased metal concentration in coarse fractions may be credited to the ability of coarse particles to better document anthropogenic inputs, due to the limited transport and longer residence time of these fractions in any specific site..$^{33}$ Since there are no reported anthropogenic sources of $\mathrm{Al}$ in the region, the inverse relation may result from dilution of $\mathrm{Al}$ and $\mathrm{Fe}$ phases in the fine fraction with weathered clays of low scavenging capacity for metals.

The Fe concentrations (see Table 5) show moderate variations (standard deviation of $20 \%$ ) along the cores of the different stations. There are no noteworthy trends with depth and when evaluating the entire data set significant correlation of $\mathrm{Fe}$ with other metals (see Table 4) were found, although only for $\mathrm{Ni}$ and $\mathrm{Al}$ correlations coefficients are $>0.6$. The Fe concentrations are of the same order of magnitude as those in sediments of the Guanabara Bay (see Table 6).

The relative standard deviation of the Mn average contents varied from 16 to $36 \%$. Depth profiles display a slight concentration growth towards the bottom in $\mathrm{P}, \mathrm{NO} 2$ and $\mathrm{S} 1$; however, in the other stations profiles are irregular and show no evident trends.

Mn concentrations $\left(361 \pm 99 \mathrm{mg} \mathrm{kg}^{-1}\right)$ at the fringe in NO1 were twice as large as in the other stations. Mn may be present in recent sediments as manganese oxide, manganese carbonate or manganese sulfide. The presence and abundance of a certain solid phase depends on the prevailing redox condition, on the $\mathrm{pH}$ and also

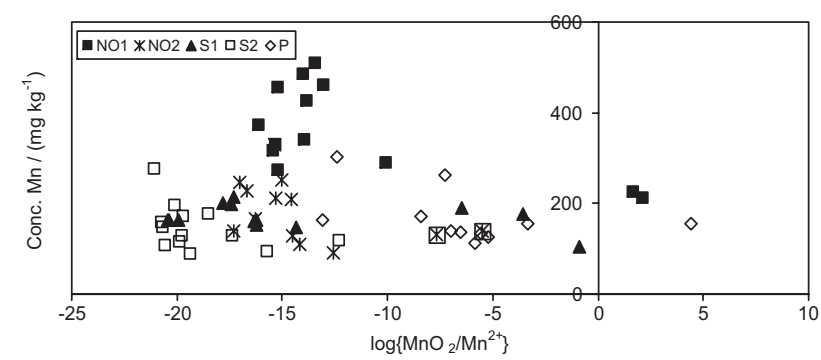

Figure 5. Plot of equilibrium activities ratios of manganese species, calculated using measured $\mathrm{pH}$ and Eh versus the manganese concentration found in sediments.

Table 6. Metal concentration ( $\mathrm{mg} \mathrm{kg}^{-1}$ except Fe in \%) in several mangrove areas and in Guanabara Bay (GB) sediments. DL stands for detection limit

\begin{tabular}{|c|c|c|c|c|c|c|c|c|c|}
\hline Region & $\mathrm{Fe}$ & Mn & $\mathrm{Ni}$ & $\mathrm{Zn}$ & $\mathrm{Cu}$ & $\mathrm{Cd}$ & $\mathrm{Pb}$ & $\mathrm{Al}$ & Reference \\
\hline Guanabara Bay, Brazil & & & $1.0-9.6$ & $1.23-174.8$ & $<\mathrm{DL}$ & & $<\mathrm{DL}$ & & 8 \\
\hline Guapimirim Mangrove (GB, Brazil) & & 273 & & 26.7 & 28.3 & & 26.0 & & 11 \\
\hline Governador Island Mangrove (GB, Brazil) & & 150 & 6.0 & 263 & 80 & & 130 & & 11 \\
\hline São Gonçalo Mangrove (GB, Brazil) & & 71.7 & 8.7 & 610 & 18 & & 20.0 & & 11 \\
\hline Peteca Mangrove (GB, Brazil) & & 80.0 & 10.3 & 53.3 & 46.7 & & 86.7 & & 11 \\
\hline Guanabara Bay $(0-6 \mathrm{~cm})$ & 4.3 & & & 505.1 & 79.6 & & 169.5 & & 36 \\
\hline Guanabara Bay (surface sediment) & & & & 78-707 & $2.1-300$ & $0.02-2.6$ & $3.6-110$ & & 7 \\
\hline Sepetiba Bay (Brazil) & & & & $18.1-795$ & $2.1-166$ & $0.5-87$ & $6.5-85.7$ & & 6 \\
\hline Mangroves (Sinnamary) French Guyana & 4.4 & 539 & 31.7 & 164 & 17.8 & & 26.9 & & 37 \\
\hline Piedade Mangrove (GB, Brazil) & $1.4-2.3$ & $112-304$ & $3.5-4.3$ & $28-43$ & $0.01-0.1$ & $0.01-0.2$ & $11-17$ & $4.9-6.2$ & Present study \\
\hline Nova Orleans Mangrove (GB, Brazil) & $0.9-3.3$ & $92-509$ & $3.6-9.4$ & $23-59$ & $2.2-6.3$ & $0.05-0.2$ & $6.5-12$ & $4.2-9.1$ & Present study \\
\hline Surui Mangrove (GB, Brazil) & $1.3-2.5$ & $88-277$ & $3.6-8.3$ & $16-63$ & $2.3-6.2$ & $0.03-0.2$ & $8.3-19$ & $6.0-14$ & Present study \\
\hline
\end{tabular}

1- Digestion in $\mathrm{HNO}_{3}$, FAAS determination; 2- Digestion in $\mathrm{HNO}_{3}+\mathrm{HClO}_{4}$, FAAS determination; 3- Digestion in $\mathrm{HNO}_{3}+\mathrm{HF}$, GFAAS determination; 4- Digestion in $\mathrm{HNO}_{3}$, GFAAS determination; 5- Microwave extraction in $\mathrm{HCl}, \mathrm{HNO}_{3}$ and $\mathrm{H}_{2} \mathrm{O}$ (1:1:1), ICP-EAS determination. 
on the availability of carbonate ions in the case of $\mathrm{MnCO}_{3}$ precipitation. Mn (IV) under the form of $\mathrm{MnO}_{2(\mathrm{~s})}$, reduces to $\mathrm{Mn}^{2+}$ at $\mathrm{pE}^{\mathrm{o}}(\mathrm{pH}=7.0)$ close to + 8.9. ${ }^{30}$ Figure 5 shows the estimative for the $\mathrm{MnO}_{2(\mathrm{~s})}$ and $\mathrm{Mn}^{2+}$ activities ratio calculated based on the following equilibrium equation $\left\{\gamma \mathrm{MnO}_{2(\mathrm{~s})}\right\} /\left\{\mathrm{Mn}^{2+}\right\}=-43+4 \mathrm{pH}$ $+2 \mathrm{pE}$, on $\mathrm{pH}$ and Eh data. This plot points out that most sediment samples had redox conditions that allow, at different intensities, the reduction of Mn (IV) to Mn (II). Since sulfides should not be formed in the measured Eh range, $\mathrm{Mn}^{2+}$ may then form $\mathrm{MnCO}_{3}$ in the presence of carbonate ions. Precipitation of $\mathrm{MnCO}_{3}$ will be favored where higher $\mathrm{pH}$ values are found and, in the case of the studied area, where seawater inputs are more prominent since this is the major source of inorganic carbon. Due to the geology of the Guanabara hydrographic basin shaped with rocks rich in feldspar, mica and quartz, river waters in the region are typically low in carbonates in comparison to seawater. ${ }^{3}$ Surui is located between branches of rivers and Piedade lay in the region where the largest rivers of the bay flow into. It is reasonable to assume that inorganic carbon will be less abundant in these sites than in NO. The wellknown key $\mathrm{pH}$ role in controlling carbonate precipitation led to the following observations: in Piedade, the highest Mn values are found at the deepest segments of the core, in which higher $\mathrm{pH}$ values have been determined; in Nova Orleans, the highest $\mathrm{Mn}$ concentrations also occur at $\mathrm{pH}$ above 7; in Suruí, with more acidic sediments, the average of concentrations is lower than in Nova Orleans.

Figures 6 shows the depth profiles for the $[\mathrm{MeHCl}] /$ $\left[\mathrm{MeHNO}_{3}\right]$ ratios. General increasing trends in the "simultaneously extracted metal" superimposed to fluctuations are found for $\mathrm{Cd}$ in $\mathrm{NO}$, notably in the fringe station, as well as for $\mathrm{Cd}$ and $\mathrm{Pb}$ in Piedade. Increasing trends in the upper $20 \mathrm{~cm}$ of sediment column are also present in several of the depth profiles $(\mathrm{Pb}$ in $\mathrm{NO} 1 ; \mathrm{Cu}$ in $\mathrm{NO} 1$ and $\mathrm{NO} 2 ; \mathrm{Pb}$ in $\mathrm{S} 1$ and $\mathrm{S} 2, \mathrm{Cu}$ in $\mathrm{S} 1 ; \mathrm{Cd}$ in $\mathrm{S} 2$; and $\mathrm{Zn}$ in S2). These trends may be indicative of increasing contamination.

$\mathrm{Ni}$ is the only metal for which the highest percentages of the "simultaneously extracted" fraction (from 49 to $81 \%$ ) are highly correlated with AVS ( $r=$ $0.943 ; \mathrm{p}<0.05$ ). This should be expected if sulfides are abundant enough in such cases to precipitate $\mathrm{Ni}$ as insoluble sulfide. In Nova Orleans, the "simultaneously extracted" Ni percentage was from 2 to $4 \%$, far below those in Piedade, although the AVS is found at the same concentration range in these two areas. These observations point out large heterogeneities in the distribution of metals among phases in sediments and show the difficulty of performing a geochemical evaluation in complex environments such as mangroves.

$\mathrm{Pb}$ and $\mathrm{Cu}$ in the "simultaneously extracted" fraction showed the strongest correlations to AVS as given in Table 4 .

A considerable fraction, from 11 to $15 \%$, of aluminum was obtained through treatment with $\mathrm{HCl}$. In Piedade, the $\mathrm{AlHCl}$ concentrations ranged from 454 to $1269 \mathrm{mg} \mathrm{kg}^{-1}$ and there was a slight increase with depth. In Nova Orleans and Suruí, concentrations in $\mathrm{HCl}$ remained almost constant along the profile.

Metal concentrations in the studied areas are, in general, lower than those shown for other areas in Table 6 . They are generally inferior to those reported for Guanabara Bay sediments. Zn, besides the possible industrial origin, is a component of domestic sewage and may be found at elevated concentrations in environments that receive loads of raw sewage such as the Guanabara Bay. However, in the studied mangroves, $\mathrm{Zn}$ concentrations are generally lower than those reported for the bay (see Table 4) and there is no significant concentration difference $(p<0.05)$ among the mangrove areas. $\mathrm{Mn}$ and $\mathrm{Ni}$ concentrations are within the range reported by Machado et al. ${ }^{11}$ for other mangrove areas in Guanabara Bay, and are similar to the lowest values found in the bay sediments by Perin. ${ }^{8}$ The lower metal concentrations in the mangrove sediments compared to the bay may be due to a dilution effect caused by the elevated sediment transport to the studied areas suggested by either the uniform or fluctuating ${ }^{210} \mathrm{~Pb}$ activities. The comparison of data surveyed in literature with those of the present work is limited by differences in methodologies employed in the treatment of samples.

The assessment of contamination levels in sites with sediments of different grain size may be better elaborated if data are normalized in relation to the fraction containing these contaminants $(<63 \mu \mathrm{m})$. This normalization pointed out that among the three studied mangroves, Suruí shows the highest contamination level. $\mathrm{Zn}$ and Ni in Surui are twice as high as in Nova Orleans and three times higher than in Piedade. After normalization, the contamination level in the different mangroves can be discriminated as follows: $\mathrm{P}<\mathrm{NO}<$ $\mathrm{S}$. This ordering concurs with the Surui proximity to major potential contamination sources in the Guanabara Bay.

It is worth mentioning that, for metals presenting established recommended maximum levels such as $\mathrm{Cd}$, $\mathrm{Cu}, \mathrm{Pb}, \mathrm{Ni}$ and $\mathrm{Zn}$, all concentrations were below the TEL values suggested by Buchman. ${ }^{34}$ 

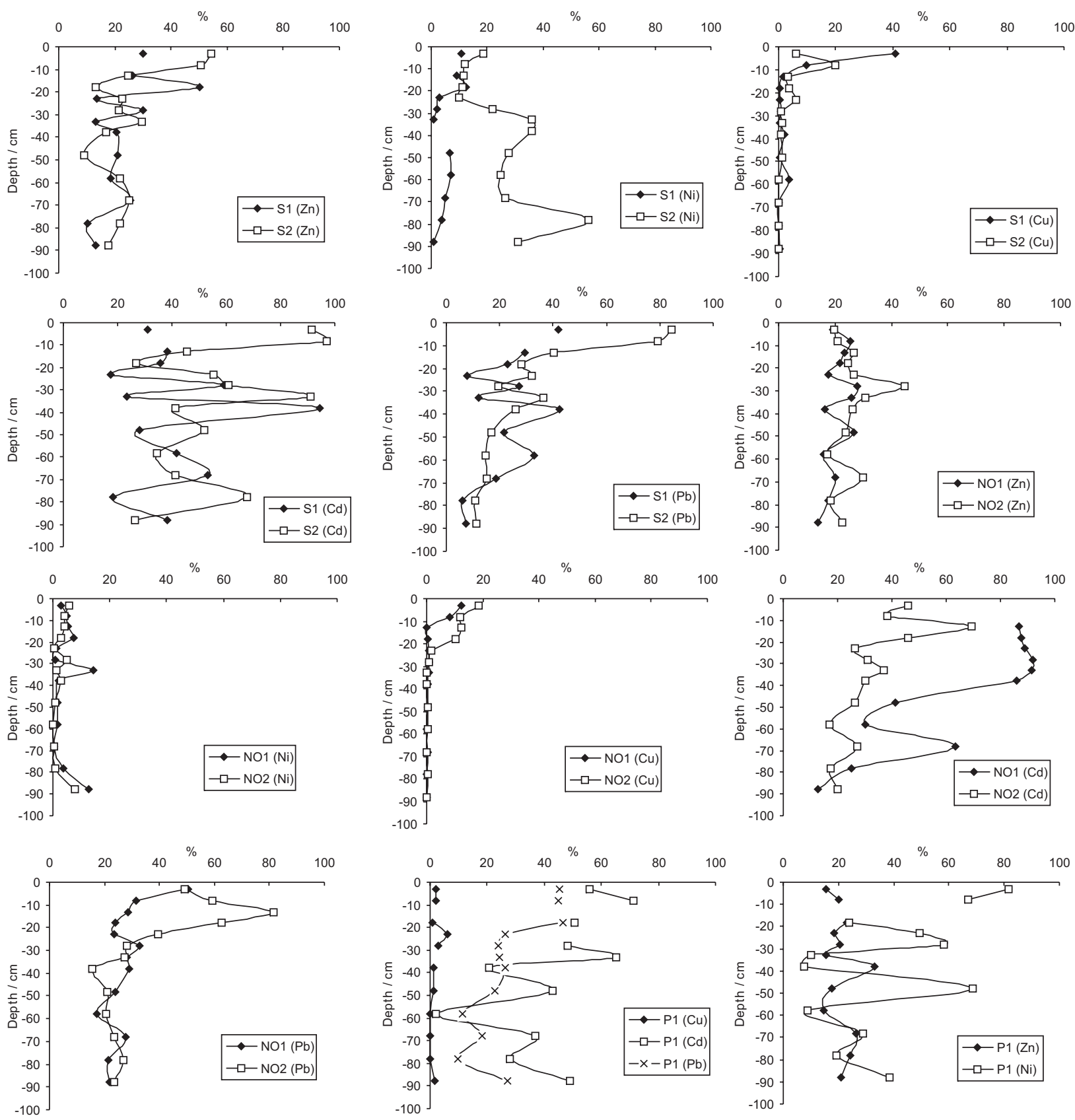

Figure 6. Depth profiles of $[\mathrm{MeHCl}] /\left[\mathrm{MeHNO}_{3}\right]$ ratios (\%) in sediments of Surui (S1 and S2), Nova Orleans (NO1 and NO2) and Pidade (P).

\section{SEM/AVS}

According to Ankley the SEM/AVS ratio is more suitable to evaluate the bioavailability potential in sediments with AVS concentrations equal to or greater than $1 \mathrm{mmol} \mathrm{L}{ }^{-1} \cdot{ }^{35}$ At lower concentrations, other solid phases may determine the level of metals that will be found in the aqueous phase (interstitial water) and, therefore, potentially bioavailable. AVS values obtained in this work are fairly inferior to this level.
In spite of the generally low metal concentration found in the sediments, the SEM/AVS ratio in the deepest layers in Piedade and Nova Orleans and in the surface sample of the Suruí (S1) were higher than 1. This fact alone cannot be taken as indicative of potential toxicity because of the reduced AVS concentrations and the weak or lack of correlation between metal concentration and AVS. In as much, predominant $\mathrm{HCl}$-extracted fractions of about $20 \%$ or lower imply in the presence of metals under physicalchemical forms which are principally not bioavailable. 
Consolidated $\mathrm{Fe}$ and $\mathrm{Mn}$ oxides may be found among these other phases controlling metal solubility. Cadmium was an exception by showing high reactivity in $\mathrm{HCl} 1 \mathrm{~mol} \mathrm{~L}^{-1}$, with an average removal of 33 to $66 \%$, and maxima above $90 \%$, not associated with AVS.

\section{Conclusions}

The present work demonstrates the difficulty of studying contamination in sediments of mangrove areas. Reliable geochronological evaluations were impaired by bioturbation and large sediment transport events that lead to disturbance of the ${ }^{210} \mathrm{~Pb}$ sedimentary record. Correlations found between variables whenever present are weak and sometimes hold only for part of data from the same core.

Substantive formation of sulfides in such ecosystem during high tide followed by almost complete oxidation during the low tide period seems unlikely, since redox as well as precipitation and dissolution reactions are hindered by kinetic factors. The presence of high concentrations of organic carbon in the studied environment of moderate anoxia, subjected to exudation of molecular oxygen by roots and high temperatures all over the year, suggests that this organic matter is of refractory nature. The low concentration of sulfide found in deeper sediment layers, even lower than in surface sediments which receive inputs of fresh organic substrates, strongly supports this hypothesis.

The organic matter plays important role in the sorption and complexation of transition metals. The treatment with $\mathrm{HCl}$ provides a medium sufficiently acid for the established $\mathrm{pH}$ to be lower than $\mathrm{pK}_{\mathrm{a}}$ of humic acids (log $\mathrm{pK}_{\mathrm{a}}$ close to 5.5), thus allowing the release of metals from humates. In the mangrove area flooded with seawater, there is a possibility for carbonates to precipitate, to which some metals may be associated, for example, $\mathrm{Cd}$. In the present work, the low AVS contents, the presence of oxidized sediments or sediments, in general, suboxic lead to the conclusion that metals obtained through extraction with $\mathrm{HCl}$ are mainly originated from the above phases (humics and carbonates) and from unconsolidated iron and manganese oxo-hydroxides. There are also evidences that some reduction of sulfate and subsequent precipitation and stabilization of sulfides may proceed in microenvironments in the sediments. This explains the presence of AVS in sediments with overall Eh above $0 \mathrm{~V}$.

Despite the difficulties verified above, a careful evaluation of data permitted to discriminate different contamination levels of the studied mangroves, which may be classified, in general, as low.

\section{Acknowledgments}

The authors acknowledge the financial support from CAPES, CNPq and FAPERJ, and are grateful to the Geological Oceanography Laboratory-Universidade Estadual do Rio de Janeiro for the grain size determination.

\section{References}

1. IBGE; Sinopse Preliminar do Censo Demográfico de 1991, Fundação Instituto Brasileiro de Geografia e Estatística: Rio de Janeiro, 1991.

2. JICA.; The study on Recuperation of the Guanabara Bay Ecosystem, Kokusai Kogyo Co.: Tokyo, 1994.

3. Amador, E.S.; Baía de Guanabara e Ecossistemas Periféricos: Homem e Natureza, Reproarte Gráfica e Editora: Rio de Janeiro, 1987.

4. Soares, M.L.G.; Ph.D. Thesis, Universidade de São Paulo, São Paulo, Brazil, 1997.

5. Harbison, P.; Mar. Pollut. Bull. 1986, 17, 246.

6. Lacerda, L. D.; Pfeiffer, W. C.; Fiszman, M.; Sci. Total Environ. 1987, 65, 163.

7. Rebello, A.; Haekel, W.; Moreira, I.; Santelli, R.; Schroeder, F.; Mar. Chem. 1986, 18, 215.

8. Perin, G.; Fabris, R.; Manente, S.; Wagener, A. de L.R.; Hamacher, C.; Scotto, S.; Water Res. 1997, 31, 3017.

9. Machado, W.; Carvalho, M. F.; Santelli, R. E.; Maddock, J. E. L.; Mar. Pollut. Bull. 2004, 49, 89.

10. Machado, W.; Silva-Filho, E. V.; Oliveira, R. R.; Lacerda, L. D.; Mar. Pollut. Bull. 2002, 44, 1277.

11. Machado, W.; Moscatelli, M.; Rezende, L. G.; Lacerda, L. D.; Environ. Pollut. 2002, 120, 455.

12. Di Toro, D.M.; Mahony, J.; Hansen, D.; Scott, K.; Carlson, A.; Ankley, G.; Environ. Sci. Technol. 1992, 26, 96.

13. Clark, M.W.; McConchie, D.; Lewis, D.W.; Saenger, P.; Chem. Geol. 1998, 149, 147.

14. Hutchings, P.A.; Saenger, P.; Ecology of Mangroves, University of Queensland Press: St. Lucia, 1987.

15. Defew, L.H.; Mair, J.M.; Guzman, H.M.; Mar. Pollut. Bull. 2005, 50, 547.

16. Silva, C.A.R.; Lacerda, L.D.; Rezende, C.E.; Biotropica 1990, 22, 339.

17. Tam, N.F.Y.; Wong, Y.S.; Environ.Pollut. 2000, 110, 195.

18. Cooper, D. C.; Morse, J. W.; Environ. Sci. Technol. 1998, 32, 1076.

19. Jacobs, L.; Emerson, S.; Skei, J.; Geochim. Cosmochim. Acta 1985, 49, 1433.

20. Casas, A.M.; Creselius, E.A.; Environ. Toxicol. Chem. 1994, 13, 529.

21. Rickard, D.; Morse, J. W.; Mar. Chem. 2005, 97, 141.

22. Mackey, A. P.; Mackay, S.; 1996. Environ. Pollut. 1996, 93 , 205 
23. Nudi, A. H.; Ph.D. Thesis, Pontificia Universidade Catolica do Rio de Janeiro, Rio de Janeiro, Brazil, 2005.

24. Soares, M. L.G.; Silva Jr., C.M.G.; Cavalcanti, V.F.; Almeida, P.M.M.; Monteiro, A.S.; Chaves, F.O.; Duque Estrada, G.C.; Barbosa, B.; Geochim. Bras. 2006, 20, 54.

25. Allen, H. E.; Fu, G.; Boothman, W.; DiToro, D. M.; Mahony, J. D.; EPA 1991.

26. Folk, R.L.; Ward, W.C.; J. Sed. Petrol. 1957, 27, 3.

27. Godoy, J.M.; Moreira, I.; Wanderley, C.; Simões Filho, F.F.; Mozeto, A.A.; Radiat. Prot. Dosimetry 1998, 75, 111.

28. Walsh, J.P.; Nittrouer, C.A.; Mar. Geol. 2004, 208, 225.

29. Amador, E.S.; ABEQUA, 1992, 199.

30. Stumm, W.; Morgan, J. J.; Aquatic Chemistry, $3^{\text {rd }}$ ed., Wiley: New York, 1996.
31. Lacerda, L. D.; Carvalho, C. E. V.; Tanizaki, K. F.; Ovalle, A. R. C.; Rezende, C. E.; Biotropica 1993, 25, 252.

32. Wagener, A.L.R.; Quim. Nova 1995, 18, 534.

33. Tessier, A.; Campbell, P.G.C.; Bisson, M.; J. Geochem. Explor. 1982, 16, 77.

34. Buchman, M.F.; NOAA Screening Quick Reference, National Oceanic and Atmospheric Administration: Seattle, 1999.

35. Ankley, G.T.; DiToro, D.H.;Hansen, D.J.; Berry, W.; Environ. Toxicol. Chem. 1996, 15, 2056.

36. Kehring, H. A.; Pinto, F. N.; Moreira, I.; Malm, O.; Org. Geochem. 2003, 5, 491.

37. Marchand, C.; Lallier-Verges, E.; Baltzer, F.; Albéric, P.; Cossa, D.; Baillif, P.; Mar. Chem. 2005, 98, 1.

Received: February 2, 2007

Web Release Date: September 19, 2007 